\title{
Review: Bahan Alami Penyembuh Luka
}

Dede Jihan Oktaviani', Shella Widiyastuti' ${ }^{1}$ Dian Amalia Maharani ${ }^{1}$, Agni Nur Amalia², Asep Maulana Ishak ${ }^{3}$, Ade Zuhrotun ${ }^{4,5^{*}}$

1Program Studi Sarjana Farmasi, Fakultas Farmasi, Universitas Padjadjaran, 2Program Studi Sarjana Perikanan, Fakultas Perikanan dan Ilmu Kelautan, Universitas Padjadjaran, 3Program Studi Sarjana IImu Kelautan, Fakultas Perikanan dan Ilmu Kelautan, Universitas Padjadjaran, ${ }^{4}$ Pusat Studi Pengembangan Pembelajaran, Fakultas Farmasi, Universitas Padjadjaran,

${ }^{5}$ Departemen Biologi Farmasi, Fakultas Farmasi, Universitas Padjadjaran email: ade.zuhrotun@unpad.ac.id

(Submit 5/8/2019, Revisi 6/8/2019, Diterima 8/8/2019)

\begin{abstract}
Abstrak
Prevalensi luka yang cukup tinggi di Indonesia (8,2\%) pada tahun 2013 yang diakibatkan oleh kasus terjatuh (40,9\%) dan transportasi kendaraan bermotor $(40,6 \%)$ memerlukan perhatian berbagai pihak. Diantaranya melalui upaya menumbuhkan kesadaran para pengguna jalan dan edukasi masyarakat akanpentingnya keselamatan. Review ini merupakan hasil penelusuran pustaka yang bertujuan memberikan pengetahuan umum mengenai luka dan bahan alami untuk menyembuhkan luka. Jenis luka yang terjadi bermacam-macam berdasarkan penyebab dan ada tidaknya kontaminasi, yang semuanya memerlukan perawatan agar proses penyembuhan berlangsung cepat. Beberapa bahan alami yang telah terbukti dapat membantu menyembuhkan luka diantaranya yaitu papaya (carica papaya), babadotan (Ageratum conyzoides), pegagan (Centela asiatica), jarak (Jatropa curcas), kunyit (Curcuma domestica), singkong (Manihot esculenta) dan pisang (Musa paradisiaca).
\end{abstract}

Kata kunci: Luka, bahan alami, menyembuhkan luka.

\section{Outline}

- Pendahuluan

- Jenis-Jenis Luka dan Mekanisme Penyembuhan

- Prinsip Perawatan Luka

- Penyembuh Luka dari Bahan Alami

- Kesimpulan

- Ucapan Terimakasih

- Daftar Pustaka

\section{Pendahuluan}

Jumlah penduduk yang mengalami luka atau cedera secara nasional di Indonesia meningkat dari 7,5\% (2012) menjadi 8,2\% (2013) yang umumnya disebabkan oleh jatuh $(40,9 \%)$ dan kecelakaan kendaraan bermotor (40,6\%). Tempat kejadian luka yaitu di jalan raya, rumah, area pertanian, dan sekolah dengan prosentase berturut-turut sebesar $42,8 \%$; $36,5 \%$; $6,9 \%$; dan $5,4 \%$. 
Luka akibat terjatuh sering dialami antara lain oleh usia dibawah satu tahun (bayi), perempuan, usia tidak sekolah, tidak bekerja dan penduduk di pedesaan. Sedangkan luka akibat transportasi kendaraan bermotor sering dialami antara lain oleh laki-laki berusia 15-24 tahun, lulus SMA, dan sudah bekerja. Jenis luka yang diderita meliputi luka lecet/memar $(70,9 \%)$, terkilir $(27,5 \%)$ dan luka robek $(23,2 \%)$ (Kemenkes $\mathrm{RI}$, 2013).

Upaya menumbuhkan kesadaran kepada para pengguna jalan raya agar lebih aman berkendara telah digelar secara serentak oleh pihak kepolisian RI melalui program nasional bertema 'Millenial Road Safety Festival' yang bertujuan Road Safety to Zero Accident (Humas Polri, 2019). Review ini berisi pengetahuan umum mengenai luka dan perawatannya termasuk penggunaan bahan atau tanaman berkhasiat sebagai penyembuh luka. Tujuannya yaitu sebagai upaya edukasi bagi pengguna jalan yang mengalami luka ataupun masyarakat lainnya yang mengalami luka.

\section{Jenis-Jenis Luka Dan Mekanisme Penyembuhan}

Luka yaitu keadaan hilang atau atau terputusnya kesatuan jaringan (kulit) yang umumnya mengganggu proses selular normal. Beberapa reaksi yang muncul jika terjadinya luka yaitu hilangnya seluruh atau sebagian fungsi organ, respon stres simpatis, pendarahan dan pembekuan darah, kontaminasi bakteri dan kematian sel (AlMuqsith, 2015; Karina dan Ismail, 2015).

Jenis luka berdasarkan penyebabnya (Al-Muqsith, 2015; Karina dan Ismail, 2015):

a) Luka lecet (Vulnus Excoriasi )

luka ini akibat gesekan dengan benda keras misalnya terjatuh dari motor sehingga terjadi gesekan antara anggota tubuh dengan aspal. Dimensi luka yaitu hanya memiliki panjang dan lebar, namun biasanya mengenai ujung-ujung syaraf nyeri di kulit sehingga derajat nyeri biasanya lebih tinggi dibanding luka robek.

b) Luka sayat (Vulnus scissum)

Jenis luka ini disebabkan oleh sayatan benda tajam misalnya logam atau kayu. Luka yang dihasilkan tipis dan kecil, yang juga bisa disebabkan karena di sengaja dalam proses pengobatan

c) Luka robek atau parut (Vulnus laseratum)

Luka jenis ini biasa karena benda keras yang merusak permukaan kulit misalnya terjatuh, terkena ranting pohon, atau terkena batu sehingga menimbulkan robekan pada kulit. Dimensi luka panjang, lebar dan dalam.

d) Luka tusuk (Vulnus punctum)

Luka terjadi akibat tusukan benda tajam, berupa luka kecil dan dalam. Pada luka ini perlu diwaspadai adanya bakteri clostridium tetani benda tajam/logam yang menyebabkan luka.

e) Luka gigitan (Vulnus morsum)

Luka jenis ini disebabkan gigitan gigi, baik itu oleh manusia ataupun binatang seperti serangga, ular, dan binatang buas. Perlu diwaspadai luka akibat gigitan dari ular berbisa yang berbahaya. 
f) Luka bakar (Vulnus combustion)

luka atau kerusakan jaringan yang timbul karena suhu tinggi. Penanganan jenis luka ini didasarka pada empat stadium luka dan prosentase permukaan tubuh yang terbakar.

Jenis luka berdasarkan kontaminasi (Al-Muqsith, 2015; Karina dan Ismail, 2015):

Luka Bersih (Clean Wounds)

Luka bersih adalah luka bedah (luka sayat elektif dan steril) yang tidak terinfeksi. Luka tidak mengalami proses peradangan (inflamasi) dan juga tidak terjadi kontak dengan sistem pernafasan, pencernaan, genital dan urinaria yang memungkinkan infeksi.

Luka bersih terkontaminasi (Clean-contamined Wounds)

Jenis luka ini adalah luka pembedahan (luka sayat elektif) dimana terjadi kontak dengan saluran respirasi, pencernaan, genital atau perkemihan dalam kondisi terkontrol. Potensi kontaminasi, bisa terjadi walau tidak selalu, oleh flora normal yang menyebabkan proses penyembuhan lebih lama.

Luka terkontaminasi (Contamined Wounds)

Luka terkontaminasi adalah luka terbuka, fresh, luka robek/parut akibat kecelakaan dan operasi dengan kerusakan besar dengan teknik aseptik atau kontaminasi dari saluran cerna.

Luka kotor atau infeksi (Dirty or Infected Wounds)

Luka kotor atau infeksi adalah terdapatnya mikroorganisme pada luka akibat proses pembedahan pembdahan yang sangan terkontaminasi. Kemungkinan terjadinya infeksi pada luka jenis ini akan semakin besar dengan adanya mikroorganisme tersebut.

\section{Prinsip Perawatan Luka}

Dalam merawat luka pertama kali dilakukan yaitu pembersihan luka semaksimal mungkin sehingga mengurangi kontaminasi pada luka dan mencegah terjadinya infeksi. Misalnya pada luka lecet dan luka parut bisa langsung dibersihkan dengan air mengalir, air hangat dan cairan antiseptic. Sedangkan pada luka tusuk dan luka gigitan perlu dibersihkan lebih maksimal untuk mengeluarkan racun atau mikroba yang mungkin terdapat pada luka. Selanjutnya bagian yang mengeluarkan darah dengan kasa steril atau kain yang bersih untuk menghentikan pendarahan sebelum perawatan luka lebih lanjut Karina dan Ismail, 2015).

Perawatan selanjutnya terhadap luka yaitu menggunakan pembalut luka (wound dressing) berupa tekstil medis dari bahan serat, benang, kain, produk komposit yang biasanya disterilkan terlebih dahulu sebelum digunakan. Pada mulanya, setiap luka dirawat supaya cepat kering termasuk luka yang mengeluarkan cairan sel (lembab) langsung dibalut dengan kain kasa. Setelah luka kering kasa biasanya lengket sehingga jaringan tumbuh lebih lambat dan memungkinkan adanya infeksi pada luka (Mutia, 2010; Purwaningsih, 2018). 
Teknik yang berkembang saat ini dikenal dengan moist wound healing atau perawatan luka berbasis lembab. Dengan menjaga kelembaban luka, maka kain kasa tidak lengket pada luka. Hasil pengamatan pasien di RSUP Dr. Sardjito yang dirawat lukanya dengan cara ini menunjukkan peningkatan epitelisasi, angka infeksi lebih rendah $(2,6 \%)$ dibandingkan perawatan konvensional $(7,1 \%)$, luka lebih cepat sembuh dan waktu inap pasien lebih sedikit (Purwaningsih, 2018)

Kain penutup luka yang kontak langsung atau primary dressing saat ini banyak dikembangkan dari produk alami, salah satunya dari sumber bahari berupa alginat. zat ini diperoleh dari rumput laut yang banyak dimanfaat diberbagai bidang termasuk untuk pengembangan tekstil medis. Diketahui, luka lebih cepat sembuh (30-50\%) apabila menggunakan pembalut yang mengandung alginat Pembalut jenis ini memenuhi syarat sebagai primer dressing yang baik diantaranya mampu menyerap cairan luka, menjaga suhu/kelembaban luka, serta mampu mengatur aliran udara/gas dari luka (Mutia, 2010). Selain alginat, modern dressings yang dikenal lainnya yaitu hydrocolloids, hydrogels, semi permeable adhesive film, foams, biological dressings dan tissue engineered skin substitutes (Qureshi et al., 2015).

\section{Penyembuh Luka dari Bahan Alami}

Sebanyak $49 \%$ penduduk Indonesia yang memanfaatkan pelayanan kesehatan tradisional, menggunakan ramuan dalam mengatasi gangguan penyakitnya. Secara nasional, penduduk Jawa Timur paling sering menggunakan ramuan obat $(65,2 \%)$ dan yang paling sedikit menggunakan yaitu penduduk Bengkulu (23,5\%) (Kemenkes RI, 2013).

Secara tradisional, beberapa masyarakat etnik tertentu di Indonesia memiliki ramuan dan cara tersendiri untuk mengobati luka, yaitu (Moektiwardoyo, 2014):

Etnik Jawa

Etnik ini memanfaatkan biji papaya sebagai obat luka. Biji papaya yang dimaksud yaitu jenis papaya kecil yang tumbuh di dataran tinggi Dieng. Biji tersebut disangrai, ditumbuk, ditambah minyak kelapa, kemudian dibalurkan pada luka

\section{Etnik Sunda}

Masyarakat etnik sunda diantaranya suku Baduy menggunakan campuran daun babadotan (Ageratum conyzoides) dan daun jampang pait (Paspalum conyugatum) untuk mengatasi pendarahan pada luka. selain itu, digunakan rimpang honje (Nicolaia speciosa) untuk mengobati luka gigitan ular dan air bonteng (Cucumis sativus) untuk mengobati luka bakar.

\section{Etnik Sasak dan Samawa di Nusa Tenggara Barat}

Etnik Sasak mengobati luka karena gigitan serangga, kalajengking dan ular, dengan cara memanfaatkan ramuan yaitu getah dan akar kethuk (Alocasia sp), daun telingan bengket (Centela asiatica), daun bebenyah (Commelia diffusa), akar dan daun bakung (Crinum asiaticum), daun empet empet (Desmodium triflorum), daun seripa (Emilia sonchifolia), getang batang jambokan (Euphorbia hirta), daun jarak (Jatropa curcas), daun kayu putih (Melaleuca cajuputi) dan daun terinjing (Sonchus oleraceus). 
Sedangkan masyarakat etnik Samawa menggunakan pucuk daun kelor (Moringa oleifera) dan Rimpang kunyit (Curcuma domestica) sebagai ramuan antiluka.

\section{Etnik Dayak di Kalimantan}

Ramuan untuk luka atau bengkak yang digunakan oleh Etnik Dayak Tunjung yaitu daun dan batang tapen atau empawa (Mallotus moluccanuss), daun marpeta (Milletia sericea), dan akar kerehau (Calicarpa longifolia). Sedangkan untuk obat luka bakar digunakan seluruh bagian tanaman krekot (Lygodium circinatum).

\section{Etnik Bali}

Masyarakat etnik Bali dalam mengobati luka pendarahan diantaranya menggunakann daun singkong (Manihot esculenta) yang ditumbuk atau kerokan batang pisang (Musa paradisiaca).

\section{Etnik Ternate}

Masyarakat etnik ternate di Maluku Utara mengobati luka dengan menggunakan daun lotifi (Acalypha hispia), daun dan akar hate salo bodubo (Agathis damara), dan daun tawa (Albizzia falcataria).

Etnik Bugis dan Minahasa di Sulawesi

Masyarakat etnik Bugis memanfaatkan batang bratawali (Tinospora crispa)untuk mengatasi gatal, kudis, luka dan demam. Ramuan lainnya untuk gatal dan alergi juga digunakan daun dan akar keloro (kelor, Moringa oleifera) ditambah air kapur barus. Sedangkan etnik Minahasa mengobati luka atau borok dengan kulit kayu telor (Alstonia scolaris) dan untuk luka bakar digunakan daun rumput ayam (Piperomia pellucida).

Beberapa tanaman yang telah digunakan oleh masyarakat etnik di Indonesia juga digunakan oleh masyarakat di India. Daftar tanaman yang digunakan di India dapat dilihat pada Tabel 1 (Beswas et al., 2003).

Tabel 1. Daftar tanaman yang digunakan sebagai penyembuh luka di India

\begin{tabular}{|c|c|c|}
\hline No & Nama Jenis & Bagian yang digunakan \\
\hline 1 & Argemone mexicana & Bunga dan getah \\
\hline 2 & Brassica juncea & Buah \\
\hline 3 & Thespesia populnea & Buah \\
\hline 4 & Pongonia pinnata & Daun \\
\hline 5 & Moringa oleifera & Daun \\
\hline 6 & Cassia alata & Daun \\
\hline 7 & Mimosa pudica & Daun \\
\hline 8 & Daucas carota & Bunga \\
\hline 9 & Calendula officinalis & Bunga \\
\hline 10 & Nerium indicum & Daun \\
\hline 11 & Datura stramonium & Daun \\
\hline 12 & Ficus religiosa & Kulit batang \\
\hline 13 & Aloe vera & Daun \\
\hline 14 & Areca catechu & buah \\
\hline
\end{tabular}


Berdasarkan hasil penelitian, beberapa bahan alami yang telah terbukti berkhasiat sebagai penyembuh dapat dilihat pada Tabel 2. Pembuktian khasiat masing-masing bahan ada yang berkaitan dengan penggunaan tradisionalnya (empiric) ataupun hasil skrining aktivitas melalui metode uji tertentu yang terkait dengan aktivitas penyembuh luka.

Tabel 2. Bahan alami yang sudah terbukti memiliki aktivitas penyembuh luka

\begin{tabular}{|c|c|c|c|c|c|}
\hline No & Nama Jenis & Nama Lokal & $\begin{array}{c}\text { Bagian yang } \\
\text { digunakan }\end{array}$ & Kandungan kimia & Pustaka \\
\hline 1 & Aloe vera L. & Lidah buaya & $\begin{array}{l}\text { Gel mengandung } 25 \% \\
\text { ekstrak etanol daun } \\
\text { lidah; } \\
\text { Krim mengandung } 10- \\
15 \% \text { ekstrak gel lidah } \\
\text { buaya }\end{array}$ & Saponin, fenol, tanin, & $\begin{array}{l}\text { Rohmawati, } \\
\text { 2008; Wijaya, } \\
2013\end{array}$ \\
\hline 2 & $\begin{array}{l}\text { Anthocleista } \\
\text { djalonensis }\end{array}$ & & $\begin{array}{l}\text { topikal } 0,2 \mathrm{ml} \text { dari } 20 \\
\mathrm{mg} / \mathrm{ml} \text { ekstrak }\end{array}$ & & $\begin{array}{l}\text { Chah et al., } \\
2006\end{array}$ \\
\hline 3 & $\begin{array}{l}\text { Anredera } \\
\text { cordifolia } \\
\text { (Ten.) Steenis }\end{array}$ & Binahong & $\begin{array}{l}\text { Salep ekstrak daun } \\
\text { binahong konsentrasi } \\
5 \% \text {; Ekstrak air hasil } \\
\text { Infusa }\end{array}$ & saponin & $\begin{array}{l}\text { Handayani, } \\
\text { 2009; Vilegas et } \\
\text { al., } 1997\end{array}$ \\
\hline 4 & $\begin{array}{l}\text { Ageratum } \\
\text { conyzoides, }\end{array}$ & Babadotan & $\begin{array}{l}\text { topikal } 0,2 \mathrm{ml} \text { dari } 20 \\
\mathrm{mg} / \mathrm{ml} \text { ekstrak }\end{array}$ & & $\begin{array}{l}\text { Chah et al., } \\
2006\end{array}$ \\
\hline 5 & $\begin{array}{l}\text { Areca catechu } \\
\text { L. }\end{array}$ & Pinang & Ekstrak Etanol Biji 2\% & $\begin{array}{l}\text { alkaloid, tanin, saponin, } \\
\text { dan flavonoid }\end{array}$ & Rairisti, 2014 \\
\hline 6 & $\begin{array}{l}\text { Carica papaya } \\
\text { L. }\end{array}$ & Papaya & $\begin{array}{l}\text { Gel ekstrak etanol daun } \\
\text { pepaya konsentrasi } 1 \text { - } \\
5 \%\end{array}$ & $\begin{array}{lr}\text { papain, } & \text { alkaloid } \\
\text { karpain, } & \text { pseudo } \\
\text { karpain, } & \text { glikosida, } \\
\text { karposid, dan } & \text { saponin }\end{array}$ & $\begin{array}{l}\text { Septiningsih, } \\
2008\end{array}$ \\
\hline 7 & $\begin{array}{l}\text { Catharanthus } \\
\text { roseus }\end{array}$ & Tapak dara & ekstrak daun $50 \%$ & $\begin{array}{l}\text { alkaloid, flavonoid, } \\
\text { tanin, polifenol dan } \\
\text { steroid }\end{array}$ & Putri, 2017 \\
\hline 8 & $\begin{array}{l}\text { Centella } \\
\text { asiatica }\end{array}$ & Pegagan & $\begin{array}{l}\text { Campuran } 3 \text { triterpen: } \\
\text { asiatic acid } 30 \% \text { (b/b), } \\
\text { madecassic acid } 30 \% \\
\text { (b/b) and asiaticoside } \\
40 \% \text { (b/b); ekstrak } \\
\text { daun pegagan } 25 \%\end{array}$ & $\begin{array}{l}\text { asiaticoside, asiatic } \\
\text { acid and madecassic } \\
\text { acid }\end{array}$ & $\begin{array}{l}\text { Maquart et al., } \\
\text { 1997; Amaliya, } \\
2013\end{array}$ \\
\hline 9 & $\begin{array}{l}\text { Colocasia } \\
\text { esculenta [L] }\end{array}$ & Talas & $\begin{array}{l}\text { Ekstrak Etanol Tangkai } \\
\text { Daun }\end{array}$ & $\begin{array}{l}\text { saponin, flavonoid, } \\
\text { tanin, alkaloid, steroid } \\
\text { dan terpenoid }\end{array}$ & $\begin{array}{l}\text { Wijayadkk., } \\
2014\end{array}$ \\
\hline 10 & $\begin{array}{l}\text { Coleus } \\
\text { atropurpureus } \\
\text { [L.] Benth. }\end{array}$ & Iler & $\begin{array}{l}\text { Hasil tumbuk } 10 \text { lembar } \\
\text { daun iler muda }\end{array}$ & flavonoid & Tari dkk., 2013 \\
\hline
\end{tabular}




\begin{tabular}{|c|c|c|c|c|c|}
\hline No & Nama Jenis & Nama Lokal & $\begin{array}{l}\text { Bagian yang } \\
\text { digunakan }\end{array}$ & Kandungan kimia & Pustaka \\
\hline 11 & $\begin{array}{l}\text { Curcuma } \\
\text { longa Linn } \\
\text { atau Curcuma } \\
\text { domestica Val. }\end{array}$ & kunyit & $\begin{array}{l}\text { Dosis kurkumin } 60- \\
66 \% \text { per oral } \\
\text { Dosis kurkumi } 10 \% \\
\text { nanofiber; } \\
\text { hidrokoloid } \\
\text { mengandung ekstrak } \\
1 \% \text {; } \\
\text { gel fraksi etil asetat } \\
\text { topikal }\end{array}$ & $\begin{array}{l}\text { kurkumin, desmetok-- } \\
\text { sikurkumin,dan } \\
\text { bisdesmetoksikurkumin } \\
\text {, minyak asiri, pati, zat } \\
\text { pahit, resin, selulosa, } \\
\text { dan mineral }\end{array}$ & $\begin{array}{l}\text { Jagetia, 2004; } \\
\text { Khan et al., } \\
\text { 2018; Julianto } \\
\text { dkk, 2016; } \\
\text { Wientarsih, } \\
2012\end{array}$ \\
\hline 12 & $\begin{array}{l}\text { Euphorbia } \\
\text { tirucalli }\end{array}$ & patah tulang & $\begin{array}{l}\text { Salep ekstrak batang } \\
\text { dosis } 10 \%\end{array}$ & $\begin{array}{l}\text { glikosida, sapogenin } \\
\text { dan asam elagat }\end{array}$ & Qomariah, 2014 \\
\hline 13 & $\begin{array}{l}\text { Gynura } \\
\text { Segetum }\end{array}$ & Daun Dewa & Lumatan daun & $\begin{array}{l}\text { saponin, flavonoid, } \\
\text { minyak atsiri }\end{array}$ & $\begin{array}{l}\text { Setyoadi dan } \\
\text { Sartika, } 2010\end{array}$ \\
\hline 14 & $\begin{array}{l}\text { Ipomoeae } \\
\text { batatas L. }\end{array}$ & Ubi Jalar & $\begin{array}{l}\text { Krim Ekstrak Etanol } \\
\text { Daun 3\% }\end{array}$ & $\begin{array}{l}\text { flavonoid, saponin dan } \\
\text { polifenol }\end{array}$ & $\begin{array}{l}\text { Rahim dkk., } \\
2011\end{array}$ \\
\hline$\overline{15}$ & $\begin{array}{l}\text { Jatropha } \\
\text { Curcas }\end{array}$ & Pohon Jarak & Getah & Flavonoid & $\begin{array}{l}\text { Priyandari, } \\
\text { 2015; Vilegas et } \\
\text { al., } 1997\end{array}$ \\
\hline 16 & $\begin{array}{l}\text { Leucaena } \\
\text { glauca, Benth }\end{array}$ & Petai cina & Gerusan daun $10-30 \mathrm{~g}$ & Flavonoid, saponin & $\begin{array}{l}\text { Rahmawati, } \\
2014\end{array}$ \\
\hline 17 & $\begin{array}{l}\text { Manihot } \\
\text { esculenta }\end{array}$ & Singkong & $\begin{array}{l}\text { ekstrak daun } 179,2 \\
\text { mg/KgBB tikus }\end{array}$ & $\begin{array}{l}\text { protein, vitamin C, } \\
\text { flavonoid, saponin, } \\
\text { tannin dan triterpenoid }\end{array}$ & Nisa dkk., 2013 \\
\hline 18 & $\begin{array}{l}\text { Melastoma } \\
\text { malabathricum } \\
. \mathrm{L}\end{array}$ & $\begin{array}{l}\text { Tumbuhan } \\
\text { Senduduk }\end{array}$ & $\begin{array}{l}\text { krim ekstrak etilasetat } \\
\text { Daun }\end{array}$ & $\begin{array}{l}\text { flavonoida, saponin, } \\
\text { tanin, glikosida, dan } \\
\text { streroida/triterpenoida. }\end{array}$ & $\begin{array}{l}\text { Simanjuntak, } \\
2008\end{array}$ \\
\hline 19 & $\begin{array}{l}\text { Morinda } \\
\text { citrifolia L.) }\end{array}$ & mengkudu & $\begin{array}{l}\text { ekstrak etanol topikal } \\
\text { daun }\end{array}$ & & Sabirin, 2013 \\
\hline 20 & $\begin{array}{l}\text { Musa } \\
\text { paradisiaca } \\
\text { var.sapientum }\end{array}$ & Pisang ambon & $\begin{array}{l}\text { gel getah pisang } 80 \% \\
\text { gel ekstrak batang }\end{array}$ & $\begin{array}{l}\text { saponin, flavonoid, } \\
\text { vitamin } C \text {, dan tanin }\end{array}$ & $\begin{array}{l}\text { Rosanto dkk., } \\
2012 \\
\text { Prasetyo dkk, } \\
2010\end{array}$ \\
\hline 21 & $\begin{array}{l}\text { Napoleonaea } \\
\text { imperialis }\end{array}$ & Lecythidaceae & $\begin{array}{l}\text { topikal } 0,2 \mathrm{ml} \text { dari } 20 \\
\mathrm{mg} / \mathrm{ml} \text { ekstrak }\end{array}$ & & $\begin{array}{l}\text { Chah et al., } \\
2006\end{array}$ \\
\hline 22 & $\begin{array}{l}\text { Ocimum } \\
\text { gratissimum }\end{array}$ & Selasih & $\begin{array}{l}\text { topikal } 0,2 \mathrm{ml} \text { dari } 20 \\
\mathrm{mg} / \mathrm{ml} \text { ekstrak }\end{array}$ & & $\begin{array}{l}\text { Chah et al., } \\
2006\end{array}$ \\
\hline 23 & $\begin{array}{l}\text { Peperomia } \\
\text { galioides }\end{array}$ & Piperaceae & $\begin{array}{l}\text { Ekstrak daun dan } \\
\text { batang (bahan segar) }\end{array}$ & & $\begin{array}{l}\text { Vilegas et al., } \\
1997\end{array}$ \\
\hline 24 & $\begin{array}{l}\text { Piper cf fragile, } \\
\text { Benth }\end{array}$ & sirih merah & $\begin{array}{l}\text { infusa daun } \\
\text { topikal }\end{array}$ & flavonoid dan tanin & $\begin{array}{l}\text { Hidayatullah, } \\
2015\end{array}$ \\
\hline
\end{tabular}




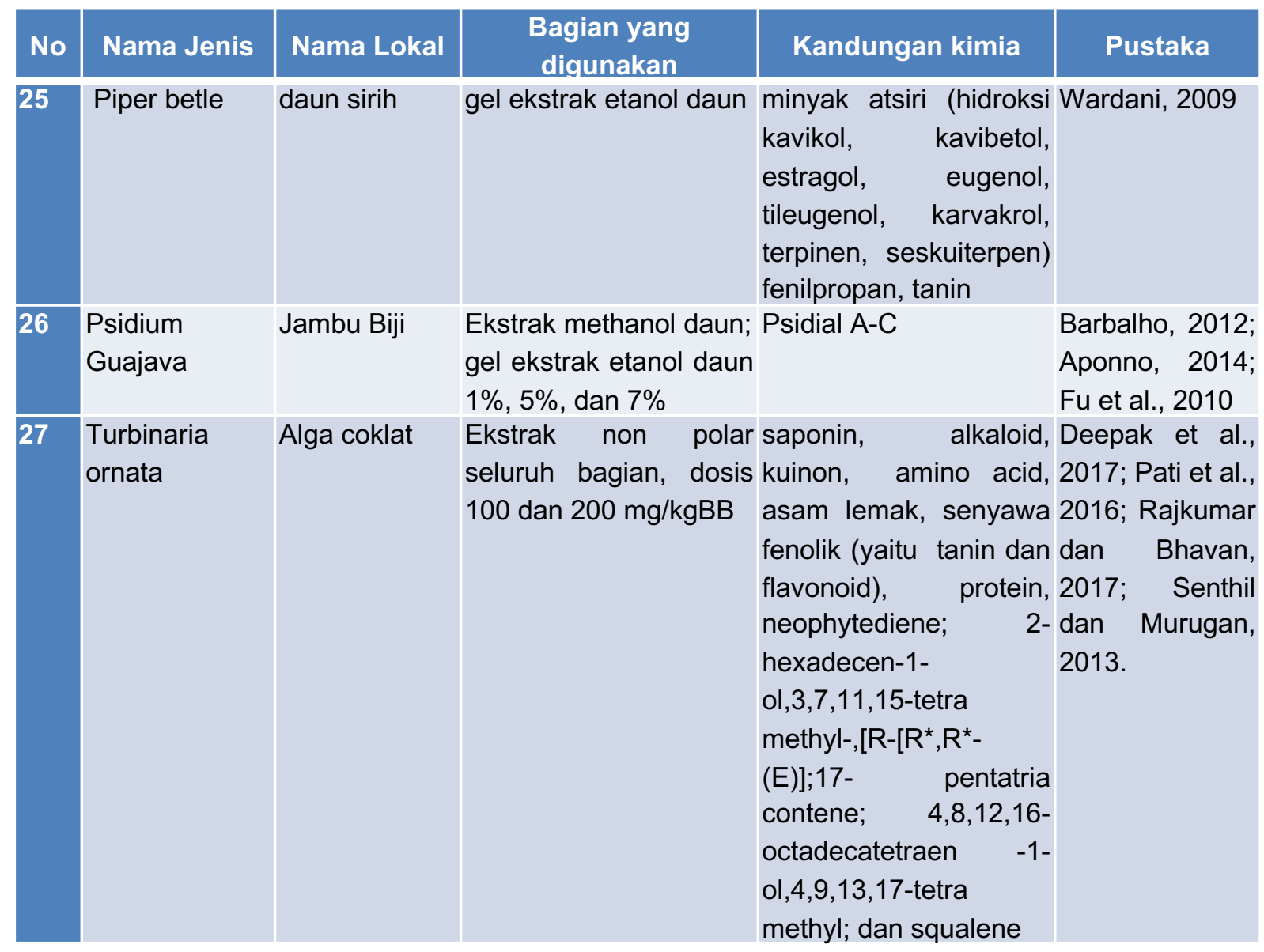

Hasil penelusuran pustaka ada sekitar tujuh tanaman yang memenuhi kriteria efikasi sebagai tanaman berkhasiat penyembuh luka berdasarkan penggunaan tradisional dan hasil pembuktian aktivitas. Tanaman yang dimaksud yaitu papaya (carica papaya) yang digunakan etnik jawa di Dataran Tinggi Dieng, babadotan (Ageratum conyzoides) yang digunakan etnik Sunda Suku Baduy, daun telingan bengket atau pegagan (Centela asiatica)dan daun jarak (Jatropa curcas) yang digunakan oleh etnik sasak, rimpang kunyit (Curcuma domestica) yang digunakan oleh etnik samawa, serta singkong (Manihot esculenta) dan pisang (Musa paradisiaca) yang digunakan oleh etnik Bali. Namun masih perlu pengembangan lebih lanjut mengenai kualitas bahan dan keamanan jika akan dikembangkan menjadi obat tradisional Jamu atau Obat Herbal terstandar.

\section{Kesimpulan}

Luka atau Cedera dapat dihindari dengan cara menumbuhkankesadaran para pengguna kendaraan bermotor dan edukasi kepada masyarakat luas mengenai keselamatan diri. Jika tidak bisa dihindari, luka yang dialami harus dirawat sebaik mungkin untuk menghindari kontaminasi/infeksi yang agar cepat sembuh. Beberapa bahan alami dapat digunakan untuk mengobati luka karena terbukti secara empiric dan melalui beberapa penelitian. Bahan tersebut diantaranya yaitu papaya (carica papaya), babadotan (Ageratum conyzoides), pegagan (Centela asiatica), jarak (Jatropa curcas), kunyit (Curcuma domestica), singkong (Manihot esculenta) dan pisang (Musa paradisiaca). 


\section{Ucapan Terima Kasih}

Terima kasih disampaikan kepada Kemenristekdikti atas dana yang telah diberikan kepada tim PKM-K Plesetan periode tahun 2019. Ucapan terima kasih juga disampaikan kepada Direktorat Pendidikan dan Kemahasiswaan, Fakultas Farmasi dan Fakultas Perikanan dan IImu Kelautan Universitas Padjadjaran sebagai fasilitator sarana dan prasarana.

\section{Daftar Pustaka}

Adam, N., W. Lolo, S. Sudewi. 2019. Aktivitas Antibakteri Fraksi Alga Turbinaria ornata (Turner) J. Agardh Yang Diperoleh Dari Perairan Teluk Manado. Pharmacon. Vol 8, No 2 (Abstrak).

Al-Muqsith, AM, 2015. Luka (Vulnus). Fakultas Kedokteran, Universitas Malikussaleh. Tersedia di repository.unimal.ac.id/4013/1/LUKA\%20\%28 VULNUS\%29.pdf. (diakses tanggal 04 Agustus 2019).

Amaliya, S., Soemantri, B., Utami, Y.W. 2013. Efek Ekstrak Daun Pegagan (Centella asiatica)Dalam Mempercepat Penyembuhan Luka Terkontaminasi Pada Tikus Putih (Rattus novergicus) Galur Wistar. Jurnal Ilmu Keperawatan. 1(1): 19-25.

Aponno, J.V, Yamlean, P.V.Y. , dan Supriati, H.S. 2014. Uji Efektivitas Sediaan Gel Ekstrak Etanol Daun Jambu Biji (Psidium guajava Linn) Terhadap Penyembuhan Luka Yang Terinfeksi Bakteri Staphylococcus Aureus Pada Kelinci (Orytolagus cuniculus). PHARMACON Jurnal IImiah Farmasi. 3(3): 279-286

Barbalho, S.M., Farinazzi-Machado, F.M.V , Goulart, R.D.A., Brunnati, A.C.S., Ottoboni, A.M.M.B., and Nicolau, C.C.T. 2012. Psidium Guajava (Guava): A Plant of Multipurpose Medicinal Applications. Medicinal and Aromatic plants. 1(4): 1-6

Biswas TK, Mukherjee, B. 2003. Plant medicines of Indian origin for wound healing activity: A review. Int $\mathrm{J}$ of low estrem wounds. 2: 25-28

Chah, K.F., Eze, C.A., Emuelosi, C.E., Esimone, C.O. 2006. Antibacterial and wound healing properties of methanolic extracts of some Nigerian medicinal plants. Journal of Ethnopharmacology. 104:164-167

Deepak, P., Sowmiya, R., Balasubramani, G., Perumal, P., 2017. Phytochemical profiling of Turbinaria ornata and its antioxidant and anti-proliferative effects. Journal of Taibah University Medical Sciences. 12 (4): 329-337

Fu, H-Z., Luo, Y-M., Li, C-J., Yang, J-Z., and Zhang, D-M. 2010. Psidials A-C, Three Unusual Meroterpenoids from the Leaves of Psidium guajava L. Organic Letters., 12(4):656-659 
Handayani, E. 2009. Uji Aktifitas Salep Ekstrak Daun Binahong (Anredera cordifolia (Ten.) Steenis) Sebagai Penyembuh Luka Bakar Pada Kulit Punggung Kelinci.skripsi. Fakultas Farmasi Universitas Muhammadiyah Surakarta

Hidayatullah, M.D. 2015. Pengaruh Pemberian Infusa Sirih Merah Secara Topikal Terhadap Waktu Penyembuhan Luka Insisi Pada Tikus Putih Jantan Galur Wistar.Skripsi. Fakultas Kedokteran Universitas Islam Bandung

Humas Polri, 2019. "Millenial Road Safety Festival" Wujudkan Millenial Cinta Lalu Lintas. Biro Pengelola Informasi dan Dokumentasi, Divisi Humas Polri. Tersedia di: https://humas.polri.go.id/download/millenial-road-safety-festival-wujudkan-millenialcinta-lalu-lintas/ (diakses tanggal 04 Agustus 2019)

Jagetia, G.C, Rajanikant, G.K. 2004. Role of curcumin a naturally occurring phenolic compound of turmeric in accelerating the repair of excision wound in mice whole body exposed to various doses of gamma radiation. J of Surgical Res. 120: 127-138

Julianto, E., Mardiyono, dan Santoso, B. 2016. Efektifitas Hidrokoloid Kunyit (Curcuma domestika) Terhadap Proses Penyembuhan Luka Diabetik Stadium I Pada Tikus (Rattus novergitus). Tesis Magister. Program Studi Magister Epidemiologi Program Pascasarjana Universitas Diponegoro

Kemenkes RI. 2013. Riset Kesehatan Dasar. Badan Penelitian Dan Pengembangan Kesehatan Kementerian Kesehatan RI.47-49

Khan AR, Xiangyang S, Ahmad A and Mo X. Electrospinning of Crude Plant Extracts for Antibacterial and Wound Healing Applications: A Review. SM J Biomed Eng. 2018; 4(1): 1024

Maquart FX, Chastang F, Simeon A, Biremburt P, Gillery P. Triterpenes from Centella asiatica stimulate extracellular matrix accumulation in rat experimental wounds. Euro $\mathrm{J}$ of Derma. 9: 289- 296.(1997)

Moektiwardoyo, M. 2014, Etnofarmasi, Edisi 1, Yogyakarta: Deepublish

Nisa, V.M., Meilawaty, Z., Astuti, P. 2013. Efek Pemberian Ekstrak Daun Singkong (Manihot esculenta) Terhadap Proses Penyembuhan Luka Gingiva Tikus (Rattus norvegicus) (The Effect of Cassava Leaves Extract (Manihot esculenta) on Gingival Wound Healing Rats (Rattus norvegicus). Artikel Ilmiah Hasil Penelitian Mahasiswa. Tersedia di www.academia.edu (diakses tanggal 05 Agustus 2019)

Pati, M.P, S. D. Sharma, L. Nayak, C. R. Panda. 2016. Uses Of Seaweed And Its Application To Human Welfare: A Review. International Journal of Pharmacy and Pharmaceutical Sciences. Vol 8 (10): 12-20

Prasetyo, B.F., Wientarsih, I., Priosoeryanto, B.P., 2010. Aktivitas Sediaan Gel Ekstrak Batang Pohon Pisang Ambon dalam Proses Penyembuhan Luka pada Mencit. Jurnal Veteriner. 11(2): 70-73 
Priyandari, Y. , dan Umatjina, S.A.T.M., 2015. Getah Pohon Jarak (Jatropha Curcas) Topical Mempercepat Lama Penyembuhan Luka Eksisi Mencit. Journals of Ners Community. 6(2):199-206

Purwaningsih, L.A., 2018. Perawatan Luka Modern di RSUP Dr Sardjito Yogyakarta. Unit Promosi Kesehatan Rumah Sakit RSUP Dr Sardjito Yogyakarta. Tersedia di https://sardjito.co.id/2018/05/22/perawatan-luka-modern-di-rsup-dr-sardjito-yogyakarta/ (diakses tanggal 04 Agustus 2019)

Putri, R.R., Hakim, R.F., Rezeki, S. 2017. Pengaruh Ekstrak Daun Tapak Dara (Catharanthus Roseus) Terhadap Jumlah Fibroblas Pada Proses Penyembuhan Luka Di Mukosa Oral. Journal Caninus Denstistry. 2(1): 20-30

Qomariah, S. 2014. Efektivitas Salep Ekstrak Batang Patah Tulang (Euphorbia tirucalli) Pada Penyembuhan Luka Sayat Tikus Putih (Rattus norvegicus). Skripsi. Universitas Negeri Semarang.

Qureshi, M.A., Khatoon, F., and Ahmed, S. 2015. An Overview on Wounds Their Issues and Natural Remedies for Wound Healing. Biochemistry and Physiology. 4(3):1-9

Rahim, F., Aria,M., Aji, N.P. 2011. Formulasi Krim Ekstrak Etanol Daun Ubi Jalar (Ipomoeae batatas L.) Untuk Pengobatan Luka Bakar. SCIENTIA Jurnal Farmasi dan Kesehatan. 1(1): 21-26

Rahmawati, I. 2014. Perbedaan Efek Perawatan Luka Menggunakan Gerusan Daun Petai Cina (Leucaena galuca Benth) dan Povidone lodine 10\% dalam Mempercepat Penyembuhan Luka Bersih Pada Marmut (Cavia porcellus). Jurnal Wiyata 1(2): 227-234

Rairisti, A. 2014. Uji Aktivitas Ekstrak Etanol Biji Pinang (Areca catechu L.) Terhadap Penyembuhan Luka Sayat Pada Tikus Putih (Rattus norvegicus) Jantan Galur Wistar. Skripsi. Program Studi Pendidikan Dokter Fakultas Kedokteran Universitas Tanjungpura

Rajkumar, G. dan P.S. Bhavan. 2017. Phytochemical characterization of the marine brown alga Turbinaria ornata. Research Journal Of Chemistry And Environment. 21(3):54-63

Rosanto, Y.B., Handajani, J., Susilowati, H. 2012. Efek Pemberian Gel Getah Batang Tanaman Pisang Secara Topikal Terhadap Kepadatan Serabut Kolagen Pada Proses Penyembuhan Luka Pasca Ekstraksi Gigi Marmut. dentika Dental Journal. 17(1):34-39

Rohmawati , N. 2008. Efek Penyembuhan Luka Bakar Dalam Sediaan Gel Ekstrak Etanol 70\% Daun Lidah Buaya (Aloe vera L.) Pada Kulit Punggung Kelinci New Zealand. Skripsi, Universitas Muhammadiyah Surakarta.

Sabirin, I.R.R., Maskoen, A.M., Hernowo, B.S. 2013. Peran Ekstrak Etanol Topikal Daun Mengkudu (Morinda citrifolia L.) pada Penyembuhan Luka Ditinjau dari Imunoekspresi CD34 dan Kolagen pada Tikus Galur Wistar.Majalah Kedokteran Bandung. 45(4):226233 
Senthil, K. A., dan A. Murugan. 2013. Antiulcer, Wound Healing and Hepatoprotective Activities of The Seaweeds Gracillaria crassa, Turbinaria ornata, and Laurencia papillosa form Southeast Coast of India. Brazilian Journal of Pharmaceutical Science. 49(4): 669-678.

Septiningsih , E. 2009. Efek Penyembuhan Luka Bakar Ekstrak Etanol 70\% Daun Pepaya (Carica papaya L.) Dalam Sediaan Gel Pada Kulit Punggung Kelinci New Zealand. [Skripsi]. Universitas Muhammadiyah Surakarta.

Setyoadi, dan Sartika D.D. 2010. Efek Lumatan Daun Dewa (Gynura Segetum) Dalam Memperpendek Waktu Penyembuhan Luka Bersih Pada Tikus Putih. Jurnal Keperawatan Soedirman.5 (3): 127-135

Simanjuntak, M.R. 2008. Ekstraksi Dan Fraksinasi Komponen Ekstrak Daun Tumbuhan Senduduk (Melastoma malabathricum.L) Serta Pengujian Efek Sediaan Krim Terhadap Penyembuhan Luka Bakar. Skripsi. Fakultas Farmasi Universitas Sumatera Utara

Tari, R., Posangi, J., dan Wowor P. M. 2013. Uji Efek Daun Iler (Coleus atropurpureus [L.] Benth.) Terhadap Penyembuhan Luka Insisi Pada Kulit Kelinci (Oryctolagus cuniculus).Jurnal e-Biomedik (eBM). 1(1): 581-586

Villegas, L.F., Fernfindez,I.D., Maldonado,H., Torres, R., Zavaleta, A., Vaisberg, A.J., 2, Hammond, G.B. 1997. Evaluation of the wound-healing activity of selected traditional medicinal plants from Peru. Journal of Ethnopharmacology 55:193-200

Wardani, L. P.2009 Efek Penyembuhan Luka Bakar Gel Ekstrak Etanol Daun Sirih (Piper betle) Pada Kulit Punggung Kelinci. Skripsi. Univerversitas Muhammadiyah Surakarta.

Wientarsih, I., Winarsih, W., Sutardi, L.N. 2012.Aktivitas Penyembuhan Luka oleh Gel Fraksi Etil Asetat Rimpang Kunyit pada Mencit Hiperglikemik. Jurnal Veteriner. 13 (3):: 251-256

Wijaya, R.A. 2013. Formulasi Krim Ekstrak Lidah Buaya (Aloe vera) Sebagai Alternatif Penyembuh Luka Bakar. Skripsi, Universitas Negeri Semarang

Wijaya, B.A. Citraningtyas, G. dan Wehantouw, F..2014. Potensi Ekstrak Etanol Tangkai Daun Talas (Colocasiaesculenta [L]) Sebagai Alternatif Obat Luka Pada Kulit Kelinci (Oryctolagus cuniculus). PHARMACON Jurnal IImiah Farmasi . 3(3): 211-219 